\author{
Zh. Kantarbaeva , D. Utebayeva* \\ Al-Farabi Kazakh National University, Kazakhstan, Almaty \\ *e-mail: 28_dinar@mail.ru
}

\title{
MANIFESTATIONS AND PREREQUISITES OF RELIGIOUS EXPANSION IN THE SPIRITUAL SPHERE OF MODERN KAZAKHSTAN
}

The article deals with the problem of religious expansion, which is accompanied by a wave of globalization. In particular, the analysis of its prerequisites and its place in society and consequences is carried out, which are the basis for its widespread spread in an information, "digitized» digitized society. A description of the manifestations of evangelization and Islamization of religious expansion, which cover all spheres of spiritual life and enter through the conquest of human consciousness, is given, and the processes of their development in the information society are considered. "I'm sorry," he said, «but I don't know what you're talking about, and I don't know what you're talking about, and I don't know what you're talking about, but I don't know what you're talking about». And the possibilities of modern technologies are the basis for changing the forms and areas of use of sites of religious organizations. The article examines the social, economic, political, spiritual background and main objects of religious expansion of neo-Christian, new Islamic, neo-Christian movements, Religious Studies analysis of missionary activities carried out in the internet space and social networks, its factors contributing to the formation of religious consciousness of young people. At the same time, the features of religious expansion in cyberspace are revealed and a description of their manifestation in modern Kazakh society is given.

Key words: religious expansion, evangelism, Islamization, virtual services, cyberspace.

$$
\begin{gathered}
\text { Ж. Қаңтарбаева, А. Утебаева* } \\
\text { Әл-Фараби атындағы Қазақ ұлттық университеті, Қазақстан, Алматы қ. } \\
\text { "e-mail: 28_dinar@mail.ru }
\end{gathered}
$$

\section{Қазіргі Қазақстанның рухани саласындағы діни экспансияның көріністері мен алғышарттары}

Мақалада жаһандану толқынымен қатарласып келіп жатқан діни экспансия мәселесі қарастырылған. Әсіресеоның ақпараттық, “диджитализацияланған» цифрландырылған қоғамдағы кең етек жаюына негіз болып отырған алғышарттары мен қоғамАағы орны және салдарына талдау жасалынады. Рухани өмірдің жан-жақты салаларын қамтып, адам санасын жаулау арқылы кіріп жатқан діни экспансияның евангелизация мен исламдандыру көріністеріне сипаттама беріліп, олардың ақпараттық қоғамда даму үлерістері қарастырылады. Білім беру, қайырымдылық көмек, медициналық жәрдем беру сияқты гуманистік мақсаттарды алға қойған және діни сенімді таңдау еркіндігі сияқты ұстанымдарды ұран ете отырып, Аіни экспансияның адам санасын жаулауда түрлі әдістер мен тәсілдерді игеріп, жүзеге асыру үшін заманауи технологияларды да пайдалануда. А^ заманауи технологиялардың мүмкіндіктері діни ұйым сайттарының формалары мен пайдалану аумақтарының ауысып отыруына негіз болады. Мақалада неохристиандық, жаңа исламдық, неоориенталистік ағымдардың діни экспансиялауындағы әлеуметтік, экономикалық, саяси, рухани астарлары мен негізгі объектілері қарастырылып, интернет кеңістігі мен әлеуметтік желілерде жүргізетін миссионерлік әрекеттеріне, оның жастардың діни санасын қалыптастыруға ықпал ететін факторларына дінтанулық талдау жасалады. Сонымен қатар, киберкеңістіктегі діни экспансия ерекшеліктері айқындалып, олардың заманауи қазақстандық қоғамдағы көрінісіне сипаттама беріледі.

Түйін сөздер: діни экспансия, евангелизация, исламизация, виртуалды қызмет, киберкеңістік.

$$
\begin{gathered}
\text { Ж. Кантарбаева, А. Утебаева* } \\
\text { Казахский национальный университет имени аль-Фараби, Казахстан, г. Алматы } \\
\text { "e-mail: 28_dinar@mail.ru }
\end{gathered}
$$

Проявления и предпосылки религиозной экспансии в духовной сфере современного Казахстана

В статье рассмотрена проблема религиозной экспансии, сопровождающаяся волной глобализации. Анализируются предпосылки и слеАствия его широкого распространения в информационном, «АиАжитализированном» (цифровом) обществе. Аается характеристика 
Manifestations and prerequisites of religious expansion in the spiritual sphere of modern Kazakhstan

проявлений евангелизации и исламизации религиозной экспансии, охватывающей все сферы Ауховной жизни, завоевания человеческого сознания, рассматриваются процессы их развития в информационном обществе. Оперируя гуманистическими принципами благотворительности, знания и образования, бесплатного медицинского обслуживания и духовной помощи, религиозная экспансия охватывает все сферы человеческой жизнедеятельности, используя размичные методы и приемы миссионерской деятельности и применяя самые новейшие технологии. А возможности современных технологий на сегодняшний Аень являются основой А^я изменения форм и сфер использования сайтов религиозных организаций. В статье проводится религиоведческий анализ миссионерских методов и технологий, проводимых в интернет-пространстве и социальных сетях, а также факторов влияния на формирование религиозного сознания молодежи. Рассматриваются социальные, экономические, политические, Ауховные предпосылки и основные объекты религиозной экспансии неохристианских, новых исламских, неориенталистских течений. Кроме того, в статье выявлены особенности религиозной экспансии в киберпространстве и дана характеристика их проявления в современном казахстанском обществе.

Кмючевые слова: религиозная экспансия, евангелизация, исламизация, виртуальная деятельность, киберпространство.

\section{Introduction}

The expansion of the spiritual sphere in the current global situation, the expansion of the spiritual life of society, the expansion of the empty vacuum is determined by the conquest of religious consciousness. This phenomenon, which became widespread at the end of the XX century, is spreading through the information wave in modern post-secular society. Its manifestations and consequences in the modern world are diverse: they are characterized by changes in the lives of individuals and their development into world-class conflicts or interreligious and interethnic conflicts. Modern religious expansion is very multidimensional: it can not only bring new religious views to the secular and religious consciousness, but also affect national, political and economic issues. In the era of globalization, in the period of Kazakhstan's democratic transition, underestimation of this phenomenon leads to the destabilization of ethno-confessional relations, and on this basis, it is possible to provoke conflict and religious terrorism. Ivan Gobbozov in his work «Philosophy of Politics» notes, «There are universal laws, such as repetition of events in history, but, of course, repetition on a new basis. This is especially evident in times of troubles or crises (Gobozov, 1998: 142). J. According to Gobbozov, religious expansion often manifests itself in times of instability in society, in times of upheaval, in times of spiritual crisis. This can be estimated that the prerequisite for this phenomenon is that it lies within the framework of socio-historical features of the development or exit of a particular population to the world stage.

\section{Justification of the choice of articles and goals and objectives}

At the present stage, many political and cultural changes and processes are taking place within the framework of globalization. The Universal Information space eliminates the national and cultural differences between people living in different states, contributes to the formation of a new type of identity, the emergence of the idea of a «citizen of the world», which does not reflect national identity. This issue is closely related not only to cultural and national, but also to religious identity. In the era of information technology, it is not surprising that various ideas, including religious ones, have spread.

Methods of spiritual expansion is also widely used in developed countries to subdue developing countries using modern technologies. Therefore, a comprehensive analysis of the missionary activities of religious organizations in the internet space, which have the support of various radical groups and organizations interested in expanding their influence in other countries, is a demand today. Expansionary processes on a religious basis, carried out with the help of the virtual world in modern society, have led to the need to determine the underlying nature of this phenomenon.

\section{Scientific research methodology}

The problem of religious expansion is of great interest not only in the field of religion, but also in the fields of political science, economics, cultural studies and history. It is clear that geopolitical, economic or cultural issues are at the core of religious expansion. The following authors considered the issue of religious expansion from a geopolitical point of view: I.A. Gobbozov, A. Malashenko, 
E.E. Postol, G. Almond, H. Arendt, M. Albright, from a socio-philosophical and theological point of view, E. Drinova, M.M. Mchedlova, Y. Habermas, A.; Kazakhstani researchers: A.D. Ormanalieva, A.A. Sadikhova, Sh.S. Rysbekova, E.E. Burova, A.G. Kosichenko, N.L. Seytakhmetov.

\section{Main part}

It is clear that in the past centuries, the giant States pursued their interests and sought to expand their subordinate peoples politically, economically and territorially through the spread of religion. However, in the XX century, the entry of the existing states into the world stage, becoming independent states, contributed to a change in the policy of the countries that pursued the imperialist goal. Since this period, the importance of religious missionary organizations and missions has increased. A set of humanistic goals such as education, charitable assistance, and medical care, and advocated principles such as freedom of choice in the religious faith emerged by religious organizations. It is clear that the Missionaries of these organizations, in the process of spreading their teachings, will protect the interests of the state that support them. That is, religious expansion is an «existentialtranscendental breakthrough» that expands the sphere of influence of a particular state by gaining control of spiritual dimensions, which is realized through the conquest of a new religious consciousness (Drinova, 2009). «An important aspect of religious expansion is the ability of one person to create models of their actions, behavior, or the ability of one person to create images of religious behavior for another. An entity with authority creates ideal value models of behavior for others, relying on the system of coercion and their own power resources. The created model is an image of someone else; it is not something similar to the subject of power. In the process of introducing it into the consciousness of the object, a pattern of behavior for others developed by the subject is derived from the subject himself, his way of life and behavior.»

Historically, «we see that the growth of fanaticism coincides with a period of change. When old systems fall apart and new ones have not yet been created, there will be an explosion of all destructive forms of faith, such as bigotry, superstition and prejudice. This belief is explained by the fact that it is strengthened during periods of uncertainty as a very important ability inherent in any person» $(\mathrm{Gu}-$ seva, 2015: 74).

If we pay attention to the processes of religious expansion in modern society, the universality of its manifestation, and the underlying content, then we need to consider the issue of its coverage of existing geopolitical territories in a new way. Drinova, E. M. distinguishes the following typologies of religious expansion: civilizational-religious, state-confessional and regional-confessional - in her article» religious expansion: socio-philosophical aspect», based on historical circumstances.

"Civilizational and religious expansion is a long-term process that goes hand in hand with the conquest of vast territories, the conversion of the conquered peoples to a new faith and the formation of Christian, Islamic and Buddhist civilizations. In the late XX - early XXI centuries, the Euro-Atlantic and Islamic civilizations actively carried out civil and religious aggression. Global aggression means a struggle for the dominance of a new system of political and religious values. For example, the expansion of the Euro-Atlantic civilization presupposes the active spread and consolidation of both ideological imperatives and the values of «Protestant» ethics.

The state-confessional form of expansion is characteristic of the Middle Ages. Different ways of interpreting sacred texts and conducting religious rituals led to the emergence of denominations. Their philosophical and theological rationale played a key role in this process. The example of Christianity, in particular Orthodoxy, shows how its geopolitical ideas were implemented in the confessional space of the Eastern Church. As a result, the space of the Orthodox world was created» (Drinova, 2009). We know that the policy of Tsarist Russia to colonize Kazakhstan is at the heart of the missionary activity of baptism and Russification.

This type of regional-confessional occupation is paralleled to missionary activities. Its manifestation can be stated as the widespread distribution of non-traditional religious organizations and cults in the regions of Russia, Kazakhstan and many other post-Soviet states. In short, it is a peaceful occupation, carried out by a parable ideology.

«An important role in this process was played by the revival of religious values in the public life of the country, as well as the regional spread of Christianity and Islam» (Drinova, 2009). Islam contributed to the formation of the principles of peaceful cooperation of various religions of the Middle Volga region. The openness of borders and liberal religious legislation of Kazakhstan became the basis for the influx of non-traditional religious movements and cults, the activation of the activities of missionaries and preachers. Some of them act legally; others secretly carry out their thoughts on charity, educational courses, medical care, etc. Of course, this, in turn, affects the religious consciousness of Kazakhstanis, 
despite the fact that they are alien to their religion and mentality, traditions and realities, affects the transformation of the spiritual worldview, the denial of normal values.

It should be noted that missionary activity is aimed not only at spreading religious values, but also contributes to the formation of a positive image of the aggressor country. At the same time, the exporting countries of religious ideas actively use economic mechanisms:

- Financial assistance is provided for the construction of religious buildings;

- There are long-term programs of intensive free religious education abroad;

- Charitable organizations regularly make cash payments for missionary activities.

In modern Kazakhstan, religious expansion takes several forms. First, the spread of neo-Protestant movements. Neo-Protestant religious movements and movements were the first to realize the goals of religious expansion during the period of independence and statehood of Kazakhstan. Of course, the goals of these movements are different, some are financial and others are political. Those who know the true value and effectiveness of religious factors in solving political problems prefer to skillfully channel the potential and energy of missionaries in the right direction and use them calmly. In this case, several factors are effectively used:

Periods of economic crisis and crisis in the world and in the country as a whole. Periods when people are looking for not only material, but also spiritual support. In this case, when people are in a state of existential inevitability (unemployment, scarcity), this will be the basis for people to hope in God. This situation was exploited by the neo-Protestant movements. They offered material assistance and spiritual support. Thus, the fact of religious proselytism is clearly reflected. At the same time, a particular danger is posed by the fact that a number of foreign missionaries follow non-traditional systems that are prohibited in many Western countries.

- Periods of spiritual stress. It depends not only on economic and political factors. It is characterized by the presence of an empty space in the inner spiritual world of people. This is especially true when there are vague hopes for the future, loneliness and loneliness. This is especially true today. The conquest of human life with technological and information waves, confusing virtual life with real life, can also lead to spiritual stress. Then people go in search of the spiritual world. Missionary methods such as «subjugation by love» are especially effective in this regard.
- Periods of political instability in the world, social instability, change of values, environmental disasters, and the prevalence of human fears due to unforeseen events. For example, the spread of neomyths and rumors about the "Apocalypse» and "Apocalypse» became the basis for people to seek consolation and hope for the future in religion. It is clear that the current COVID-19 pandemic is both a cause for concern and a cause for concern. There are many religious movements that have taken advantage of this situation.

- The opening of information opportunities, the possibilities of social networks. On social media and the Internet, interesting content and missionary services of religious sites that cover all social statuses and are active for the whole society make it easy to attract people, especially young people.

The next religious expansion is associated with the conquest of the world by new Islamic movements. The above factors are also characteristic of the religious expansion of neo-Islamic movements, but the specificity of neo-Islamic expansion is characterized by resistance to Western globalization, on the one hand, and the introduction of the concept of globalization based on Islamic traditions, on the other. Other. This situation is reflected not only in the peaceful spread of Islam, but also in radical and extremist forms. This is evidenced by factors in the Middle East. Of course, the West, Russia and the United States are the main enemies of neo-Islamic movements, but in the implementation of their concepts of globalization, they effectively use both their hostile states and the peoples of Central Asia. The religious expansion of neo-Islamic movements in Kazakhstani land contradicts our traditional worldview.

- First of all, it is obvious that we are talking about the self-determination of the Kazakh people in the post-Soviet period. Self-awareness is characterized by our mentality, religion, language and traditional values. At this point, the religious position became a sensitive issue. Historically, many religions came to the Kazakh land and tried to spread, but Islam was assimilated with the nature of the Kazakh people, associated with our traditions and became an accepted religion. It should be noted that Islam was introduced peacefully, without any terror or extremism. «With the arrival of Islam on the Kazakh land, the Kazakh people perform their prayers on the basis of the school of Imam Agzam Abu Hanifa and the school of religious faith of Imam Maturidi» (Abdumanapov, 2014). However, the Russian Empire tried to deny Islam in politics. This continued from the atheistic position of the Soviet period, and the re- 
ligious consciousness of the Kazakh people has undergone some changes. However, after the collapse of the Soviet Union, the Kazakh people tried to find their roots, to define their identity. Conversion to religion began. «Kazakh youth of that time went to Arab countries such as Saudi Arabia, Egypt, Libya, Syria and Pakistan to study Islam in depth. Religiously literate youth began to work hard to spread Islam and contribute to strengthening inter-ethnic harmony and political stability. Unfortunately, there were also young people who were educated in Islam, which is unconventional for the Muslim community of Kazakhstan. These are the Wahhabism (Salafis), Hizb ut-Tahrir, Tablighi Jamaat, which are widespread in modern Kazakhstan. «The Koranists are the founders of other similar non-traditional movements» (Abdumanapov, 2014). This became the basis for the spread of many non-traditional Islamic movements with geopolitical goals:

- firstly, in Arab countries (Iran, Syria, Libya, Egypt), young people who were influenced by such non-traditional movements in the course of Islamic education were dumb mullahs who followed the same foreign ideology;

- secondly, the religious illiteracy of those who need our religious origin and seek to fill the spiritual void. That is, the inability to distinguish the teachings and rituals of traditional Islam (Hanafi) from non-traditional Islamic movements;

- thirdly, methods of active involvement of non-traditional religious movements (recruitment), systematic propaganda, the presence of a certain authority among the ideologists of foreign movements;

- fourthly, to «poison the minds» of Kazakhstani youth by involving them in social networks and the Internet.

Unfortunately, the influence of non-traditional Islamic movements has led to ethnic divisions and conflicts with traditional values. This, in turn, leads to a destructive transformation of the religious consciousness of young people. As a result, this can lead to radicalism, extremism and terrorist attacks. Young people who have undergone fundamentalist religious expansion, surrounded by the framework of fundamentalism, completely poisoned, will be ready to meet their national values and confront their homeland and even their families. Focusing on the specifics of the spread of Islam, N.J. Brown noted that «Islamists have adapted different models of political participation to the nature of the political environment in which they operate and, according$1 y$, in recent years have developed changing strategies to address issues of ideology and dogmatism» (Brown, Hamzawi, 2010: 3). Such parties and politi- cal organizations include the Muslim Brotherhood (Egypt), the Justice and Development Party (Morocco), the Islamic Constitutional Movement (Kuwait), Hamas (Palestine) and the Yemen Reform Association. «However, this trend is typical not only for Islam, but also for the Christian world, as evidenced by many European parties (Christian Democratic Union of Germany, Christian Democratic Party of Switzerland, Christian Social Party of Belgium, and Christian Democratic Party of Sweden). The tool for this is, for example, the myth of the «golden age» of a society in which a coercive social order that generates inequality is not imposed. In turn, the opposition of fundamentalism to $u$ universal ideological values is based on nationalism, which becomes an instrument of religious intervention» (Postol, 2013: 142). Researcher of the relationship between religion and politics J. Esposito noted: «There are two main political directions that are always interconnected and dominate: the movement against independence and the emergence of modern nationalism. Islam plays an important role in any of them» (Esposito, 1998: 62). «Discrediting «secular» ideologies, the reaction of the traditional foundations of fundamentalism to sustainable modernization and the establishment of the archetype of the «ideal spiritual world» in public consciousness are factors that enhance the role of fundamentalism in politics, its dominance over the degraded «secular» ideology. The second end of the problem is the procedural nature of fundamentalism» (Postol, 2013: 142). Religious aggression is fulfilled on an individual basis.

The most dangerous and troubling aspect of fundamentalism in Islam is the use of the Internet as a platform to promote terrorism. Modern terrorism has become fashionable for the modern online community. It does not have a strict hierarchy, is not tied to a specific territory, usually is not a sponsor of certain organizations and has a global character aimed at spreading terrorism.

On the Internet, you can find many groups that emerged after the outbreak of the war in Iraq. The Internet serves to recruit, promote or coordinate recruitment. When assessing the impact and effectiveness of terrorist targets, one should not be guided by access statistics, they may be false (Religious expansion of Kazakhstan, 2010). From the way Islamic fundamentalists use the Internet, it is safe to assume that cyber terrorism is on the rise.

However, fundamentalism is reflected not only in Islam, but also in the neo-Protestant movements. L. Kaplan wrote about this: «Fundamentalism - it was a religious and cultural movement that emerged in response to two influential trends in the main- 
stream Protestant denominations. First-reliable rationalization. Liberal theology and the «High Criticism» school of biblical research have worked together to reduce the supernatural and miraculous elements of Christianity in order to appeal to what is considered the spirit of the modern scientific world. A second and similar trend-replacing belief in personal salvation and prosperity with a desire to improve the social and political world» (Postol, 2013: 142). The scriptures and religious canons act as a kind of program that determines the mechanisms of the political system, reflects the style of political behavior and forms the appropriate level of political culture (Aronoff, 1984: 11-47).

When considering the issue of religious expansion, one should not lose sight of the neo-Eastern trends. It is clear that they also have their own political and financial goals. Today, such movements as the Society for Krishna Consciousness and Won Buddhism, which contribute to the transformation of the religious consciousness of Kazakhstani youth and the formation of religious views in the country, are actively carrying out their missionary work. The peculiarity of neo-eastern currents is that they are realized primarily through the promotion of oriental culture, interest in oriental exoticism, and the practical application of transcendental meditation. Unfortunately, by instilling in young people a culture that is completely alien to our national identity, they are in great danger, depriving them of their culture, national values and even families against the state.

Today, the Internet is an effective platform for religious expansion. A new trend in modern Christianity is the work of online missionaries. This includes answering their questions and chatting with unbelievers to bring them closer to God. Like any ministry, online missionary work has a number of characteristics and characteristics (Weimann, 2006).

The task of a computer network can be performed in three ways: 1) by providing information on a sheet; 2) through participation in open conversations - teleconferences or Internet forums; 3 ) by personal correspondence. An important feature of the mission on the Internet is that a person in the field is a warrior; one active person can do a lot. The audience of the Internet is mainly young people with higher education and university students. This is the largest audience for non-traditional religions. Among the thousands of Internet visitors, there are many who seek answers to life's questions from a religious point of view, from a religious point of view, and in religious debate.

One of the new trends in modern religious expansion is the specificity of the work of virtual mis- sionaries. This is done in order to answer the questions of those interested in a particular religious organization and get closer to God. Like any other service, the virtual missionary has its advantages. First, you do not have to travel around the country and knock on every door to spread your faith. Today the following features characterize religion, appeal, and missionary activity in the Internet space:

- Provides the ability to reply to messages on the Internet at a convenient time. This opportunity is appreciated by working people, students and housewives with children.

- Time to think. When dealing with an unbeliever in real life, you may not be able to think carefully about the answer and choose the words. On the other hand, online correspondence allows you to take your time, pray, and even consult with a mentor or friend.

- Revelation about «closed» people. The Internet is an opportunity for people who have difficulty discovering in real life to freely share their problems. A certain «inattention» of the Internet allows people to speak openly about what is hidden in their hearts.

- People write for themselves. Online missionary service tells you that you don't need to look for people to share the good news with. On the contrary, the Internet offers a large audience of people willing to sow the seeds of the Word.

- Global influence. Internet missionaries are not limited to countries and continents. They can reach the hearts of unsaved people, regardless of geographic location, including in countries and territories where the preaching of the gospel is prohibited.

- Own spiritual growth. According to many missionaries on the Internet, their personal life and relationship with God has changed dramatically since they started working. When we draw close to others, it is impossible to draw close to God.

- Real fruits. Internet missionaries in their correspondence talk about how their work has changed the lives of people. People find a way out of difficult situations and believe in God. This is a great source of inspiration.

- Understanding the value of each life. Many letters to Internet missionaries are filled with pain. By helping others get out of difficult situations, they realize that their love for each other is growing and they learn to value every life.

- Fearless talk about Christ. Many believers admit that they feel fear and insecurity when given the opportunity to share their beliefs in real life. Constant experience of missionary work on the Internet will allow you to gain the necessary experience and knowledge that will allow you to boldly speak about Christ not only through the Internet. 
- Complete a great mission. Christ commanded his disciples to be His witnesses throughout the world. Fulfilling this task, every Christian receives from God unchanging joy that fills his heart (Internet Missionary Work).

As a result of the use of the Internet, traditional moral norms are rapidly disappearing, and society cannot distinguish between good and evil, since any boundaries between these categories are blurred. Many clerics criticize the Internet because they understand that it negatively affects religious institutions and church hierarchy. The possibilities of publishing on the Internet are endless and information is difficult to manage. It is easy for an ignorant person to confuse false information, so it is difficult to distinguish truth from falsehood.

In general, the need for religion in the development of the Internet is associated with the development of information and communication technologies. Online religious services have raised the issue of revising traditional views and beliefs about religion. Considering that religion consists of such structural parts as religious consciousness, religious cult, religious organization, we observe the transformation of its internal content, although its appearance has not changed.

\section{Results and discussion}

The implications of the retrospective expansion of the internet space were analyzed and the factors influencing religious consciousness were identified as the result of the study. Additionally, the analysis of the context of mastering modern technologies and methods of missionary work in digitized society finalized. However, given that the possibilities of publishing any information on the internet are almost limitless, we can see that this still requires new research. Therefore, it is necessary to put the interests of national security high, underestimate the strategies and methods of work of religious associations and missions, the political, economic and ideological implications of religious expansion, and take into account the long-term consequences of their impact on society.

\section{Conclusion}

We see that religious expansion dating back to the Middle Ages is very diverse and widespread today. This can be done peacefully, with the artifacts of war, and today with the internet, but in any case, religious expansion left its mark on history, the formation of religious consciousness and even on the geopolitical issues of the state. Therefore, based on the interests of national security, it is necessary to revise the strategies and methods of work of religious associations and missions, using geopolitical categories, in order to assess the long-term consequences of their impact on society. Missionary work today is an instrument of vital change in society. This character is considered in science, technology and industrialization.

The article was fulfilled within the framework of the project «AP08053077 Missionary activity in the Internet space and its role in formation of religious consciousness of Kazakhstan's youth».

\section{References}

Абдуманапов, 3. (2014) Қазақстандағы дәстүрлі емес ислами ағымдар /https://abai.kz/post/38628

Гобозов, И.А. (1998) Философия политики. - М.: Теис. - С. 154.

Гусева, Е.С. (2015) Взаимосвязь фанатизма с феноменом нетрадиционных религиозных движений // Изв. Сарат. унив. Философский сериал. Психология. Педагогика. Т. 15. № 4. - С. 73-78. 31-36.

Дринова, Е.М. (2009) Религиозная экспансия: социально-философский аспект // Философия и общество. No. 4 (56). - C.

Постол Е.Е. (2013) Религиозная экспансия как проявление кризиса светских идеологий. // Альманах современной науки и образования, №11 (78). - С. 141-144.

Религиозная экспансия в Казахстане (2010) // https://bureau.kz/\%D0\%B1\%D0\%B5\%D0\%B7-\%D1\%80\%D1\%83\%D0\%B1 $\% \mathrm{D} 1 \% 80 \% \mathrm{D} 0 \% \mathrm{~B} 8 \% \mathrm{D} 0 \% \mathrm{BA} \% \mathrm{D} 0 \% \mathrm{~B} 8 /$ article $2086 /$

Христианство в Интернете (2017) https://studme.org/220913/sotsiologiya/hristianstvo_internete_

\section{References}

Abdumanapov, Z. (2014) Non-traditional Islamic movements in Kazakhstan /https://abai.kz/post/38628_(in Kazakh) Aronoff, M.J. (1984) «Religion and Politics». - New Brunswick: Transaction Books. - 139.

Brown N.J., Hamzawi, A. (2010) Between Religion and Politics. - Washington: Carnegie Endowment for Int'1 Peace. - 213.

Christianity on the Internet (2017) https://studme.org/220913/sotsiologiya/hristianstvo_internete_(in Russian) 
Drinova, E.M. (2009) «Religious Expansion: Socio-Philosophical Aspect» Philosophy and Society. No. 4 (56). - 31-36. (in Russian)

Esposito, J. L. (1998) Islam and Politics. $4^{\text {th }}$ ed. - NY: Syracuse University Press. -416.

Gobozov, I.A. (1998) «Philosophy of Politics». М.: Теис. - 154. (in Russian)

Guseva, E.S. (2015) «The relationship of fanaticism with the phenomenon of non-traditional religious movements» Izv. Sarat. univ. Philosophical series. Psychology. Pedagogy. ... T.15. Issue 4. - 73-78. (in Russian)

Internet Missionary Work // https://www.pravmissia.ru/internet-missionerstvo_(in Russian)

Mark Gaborio (1999) Transnational Islamic Movements: Tablighi Jama`at in Politics? // ISIM Newsletter Vol.3, Issue 1. 9 July. - Leiden: ISIM. -21.

Postol E.E. (2013) Religioznaja jekspansija kak projavlenie krizisa svetskih ideologij [Religious expansion as a manifestation of the crisis of secular ideologies]. // Al'manah sovremennoj nauki i obrazovanija, №11 (78). - 141-144. (in Russian)

Religious expansion of Kazakhstan (2010)// https://bureau.kz/\%D0\%B1\%D0\%B5\%D0\%B7-\%D1\%80\%D1\%83\%D0\%B1\%D $1 \% 80 \% \mathrm{D} 0 \% \mathrm{~B} 8 \% \mathrm{D} 0 \% \mathrm{BA} \% \mathrm{D} 0 \% \mathrm{~B} 8 /$ article_2086/(in Russian)

Weimann, G. (2006) Terror on the Internet. New arena, new challenges. Washington DC: «United States Institute for Peace Press». -3-31. 